\title{
Plan CEIBAL and the Incorporation of Digital Tools and Platforms in the Teaching of Mathematics According to the Teachers' Perceptions
}

\author{
Denise Vaillant ${ }^{1}$, Eduardo Rodríguez Zidán ${ }^{1}$, Gustavo Bentancor-Biagas ${ }^{{ }^{*}}$ \\ ${ }^{1}$ Universidad ORT Uruguay, URUGUAY
}

Received 19 June 2021 - Accepted 15 September 2021

\begin{abstract}
This article is based on research in which the three authors participated. The main objective is to identify, describe and analyze the practices of using digital tools and platforms for teaching mathematics in lower secondary education. Framed within a set of ICT policies promoted since 2007 by Plan CEIBAL in Uruguay, a mixed study was conducted, 176 teachers participated in a digital survey, and 15 of the participants were interviewed. Among the study's main results, it is worth mentioning that mathematics teachers reported a low-frequency use of digital tools and platforms, and mainly an instrumental use of digital technology. It is necessary to foster and boost the development of best practices on the use of digital tools with pedagogical meaning in the context of teacher education degree courses through more prescriptive proposals that give meaning to innovation.
\end{abstract}

Keywords: digital platforms, teaching of mathematics, secondary education, teachers' perceptions

\section{INTRODUCTION}

Uruguay is one of the countries in Latin America with the highest levels of internet coverage, students' access to digital resources, broadband development and mobile telephony, and information and communication technology penetration in homes and educational centers (Lugo \& Delgado, 2020). The digital technology policy enforced by the Uruguayan government is a pioneer among the Latin American countries and has favored a unique scenery of technological expansion. In 2007, the Educational Connectivity/Basic Computing for Online Learning Project (Plan CEIBAL, in Spanish) was created. Its fundamental purpose was promoting social equity and digital inclusion and improving the quality of education. The program is still in force and promotes the delivery of free personal computers to students of primary and secondary education and all teachers.

Plan CEIBAL has been implementing a series of support programs on technology for the teaching and learning of Mathematics in primary and secondary education for over a decade. Among the main initiatives are the Mathematics Adaptive Platform (PAM), the learning platform Contents and Resources for Education and Learning (CREA), the personal devices for students, and a wide range of digital resources. It is worth highlighting that one of the outstanding characteristics of the PAM platform is its adaptability to the different learning paces and the great variety of resources that it offers to teachers, which allows them to choose activities that fit the reality of each student.

This investigation was conducted in this national context of universal and free access to technology and digital resources for students and teachers in Uruguay. Its results are presented in this document. The study was financed by the María Viñas Fund of the National Agency for Research and Innovation in Uruguay (ANII) during 2018 and 2019.

This article presents the results referring to the Mathematics teachers' perceptions of the use of digital tools, resources, and platforms. It seeks to answer the following questions - among others:

- What are the teachers' perceptions of the use of digital platforms, tools, and applications in the Mathematics classroom? 


\section{Contribution to the literature}

- This research provides a series of good practices in the teaching of mathematics mediated by digital technology. Teachers' testimonies coincide in a favorable perspective regarding the incorporation of digital tools to their practices due to the perceived potential effect that these can have on the teaching mathematics in the classroom.

- Findings illustrate the need to generate policies to support and enhance the development of teacher development programs that stimulate good practices for the teaching of mathematics through digital technology pedagogical proposals that give meaning to the innovation.

- What is the teachers' interpretation regarding the implementation of a best practice in the use of digital resources in the teaching of Mathematics?

- What limitations and obstacles do teachers point out in the use of digital platforms?

\section{BACKGROUND}

The universal incorporation of digital technologies in the educational systems internationally and in Latin America is a relatively recent phenomenon that seeks to promote, among other effects, digital literacy, digital skills, and technological competencies of both teachers and students (OCDE, 2015).

Various reports and international studies reveal a sustained growth in policies that refer to digital tools in the last decade (Chaia et al., 2017; OCDE, 2015). Extensive literature has been produced (Arias \& Cristia, 2014; UNESCO, 2016) indicating that, with relative success and disparities, a significant number of governments have managed to enhance and reinforce the universal access to digital technologies.

The advances in Latin America regarding universal access to digital technology have been evident and achieved through different policies and programs. Among others, those which stand out are 1:1 programs at a national or subnational scale, online applications, support platforms for teaching, as well as the implementation of standards for teacher education and the development of skills with ubiquitous digital technology (Jara, 2015; Sunkel et al., 2014).

Despite the relentless promotion of governments and international organisms for the inclusion of technology with pedagogical meaning in the classroom, most teachers still prefer traditional teaching methods and resist the innovation of teaching methods in technological environments (Cabezas González \& Casillas Martín, 2019).

Among the main findings of the international survey on teaching and learning of Teaching and Learning International Survey (TALIS, 2013), it stands out that the use of technologies is a crucial factor to promote more active pedagogical practices that favor the acquisition of knowledge and competencies in students (OCDE, 2015). The aforementioned survey verified significant progress in the digital coverage of the educational systems in the
36 participating countries. However, despite the growth in access to technologies, the study demonstrated that traditional teaching methods still prevail. Seventy percent of the surveyed teachers stated that they base their teaching on a summary of the content, while $38 \%$ claimed to use information and communication technologies (ICT) in their daily teaching practices (OCDE, 2015). The survey also revealed that teachers demand adequate training in ICT to facilitate the pedagogical use they implement in the classroom (OCDE, 2015).

A few years later, the TALIS Program did a new study that revealed that the reality showed little change. In fact, the survey carried out in 2018 revealed that $56 \%$ of the teachers from the participating countries declared not having received ICT training. At the same time, the respondents demanded more training in advanced digital skills for teaching (OCDE, 2019).

Undoubtedly, the use of digital tools and platforms in teaching requires advanced skills; without them, virtual classrooms work more as appendices to the traditional teaching model rather than as a catalyst for pedagogical innovations (Area et al., 2018). The process of accumulation of technological skills and competencies by the teachers is changing, moving from a paradigm where certain teaching practices are substituted by the use of web 1.0 resources to the development of a new stage of transformation towards a new pedagogy. Nevertheless, different authors (Dussel, 2014; RiveraVargas \& Cobo-Romani, 2020) warn of the problem of integrating digital technology with its maximum potential, promoting actual transformation in teaching practices. It is argued that usually, technology is adapted to the preestablished teaching practices and pedagogical frameworks.

The "substitution" approach (Puentedura, 2006) refers to the use teachers make of digital tools to do the same as before, only now through technology. Nevertheless, some teachers do use technology to introduce changes in their teaching practices that lead to improvements, the "augmentation" approach (Puentedura, 2006). Even so, the use of digital technology occasionally enables a significant redefinition of tasks, the "modification" approach, as well as the creation of new, previously unintended tasks, the "redefinition" approach (Puentedura, 2006). 


\section{Empirical Background}

The review of the specific international literature on the teaching of Mathematics with technology provides robust evidence based on small-scale studies with quasiexperimental models regarding the benefits of using digital tools in teaching (Bansilal, 2015; Furió et al., 2014). Various researchers (Attard, 2015; Goehle \& Wagaman, 2016) point out how effective it is for the learning of Mathematics the fact that teachers use digital tools and platforms. However, these results must be considered with caution since factors such as preparation, training, and teachers' commitment to the pedagogical use of digital technologies have a notorious influence (Chauhan, 2017).

In many cases, the use of digital platforms is an appendix to the traditional teaching model. In this sense, the studies of Area et al. (2018) confirm that even with the use of digital technologies, an expository teaching method prevails without the qualitative leap towards student-centered pedagogical approaches favoring autonomous learning processes.

A teacher's Mathematics competence relates to the ability to put into action a series of technological skills that refer to mathematical reasoning to solve situations closely related to the students' world. The emphasis is on the capacities, abilities, and skills to carry out processes such as thinking, reasoning, arguing, modeling, and solving problematic situations in which knowledge, operations, the symbolic language of Mathematics, and technological tools are necessary (García Perales, 2014, 2018; OCDE, 2013).

In the case of Uruguay, and despite the expansion and widespread increase in technological resources, there is little use of technologies in the teaching of sciences. A recent study has found that future teachers in the area of natural sciences and Mathematics make moderate use of digital platforms, underutilize the digital resources promoted by the educational policies and rely little on the free web resources conducive for the learning in these areas (Rodríguez Zidán \& Grilli, 2019).

A study carried out in Uruguay by the National Institute for Educational Evaluation (ARISTAS, 2020) revealed that only $4.5 \%$ of Mathematics teachers use online assessment and one out of four teachers (23\%) use the mathematics software that comes with the laptops or the digital device provided by Plan CEIBAL. Approximately half of the teachers use GeoGebra (49\%), and only $10 \%$ use the platform CREA. One out of three of the surveyed teachers stated to use the PAM platform to support their teaching of Mathematics (INEEd, 2020).

One of the reasons that may explain this scarce pedagogical use of digital technology for the Uruguayan case could be the absence of teacher professional development policies. Some studies show that the support teachers receive for using digital tools and for strengthening their competencies and skills in Mathematics is little (Bentancor Biagas, 2017; Vaillant, 2016).

In 2015, a study in primary education on the use of PAM allowed identifying usage patterns of the platform, as well as teachers' profiles and students' attitudinal patters. The investigation showed that only $30 \%$ of the observed teachers actually used the platform. Besides, it was confirmed that in $96 \%$ of the cases, mathematics teachers used the platform mainly to revise concepts and do exercises instead of as a pedagogical support tool to promote new learnings (CEIBAL, 2015). The same conclusion is drawn by other investigations in Uruguay, which demonstrates that the variable with the highest influence regarding the probability of use is the "teacher factor" (Aboal et al., 2018).

It would seem that, among other factors, the leadership of the headmaster of the educational center is essential to promote the effective pedagogical use of technologies by the teachers. Also, the processes and curricula influence the teachers' education (Mazzotti, 2016). Moreover, in this sense, the reality is worrisome since only $40 \%$ of the trainers teach how to use digital platforms in their teacher education degree courses (Rodríguez Zidán et al., 2017).

Regarding the curricular design and teacher education in Uruguay, one investigation indicates that the curricula do not identify the digital competencies that future teachers must incorporate. As a result, it is tough to adopt curricular changes that enable the genuine inclusion of digital technologies in teacher education courses (Cabrera Borges et al., 2018).

\section{METHODOLOGY}

The investigation was based on a mixed-method, sequential, and combined, just as it is suggested by the studies of Creswell and Plano Clark (2007). This approach allowed us to meet the objectives of this study, which were:

- To look into the teachers' perceptions of the use of digital platforms, tools, and applications in the mathematics classroom.

- To gather the teachers' interpretations regarding the implementation of a best practice in the use of digital resources in the teaching of mathematics.

- To understand the limitations and obstacles pointed out by the teachers that hinder the development of best practices supported by digital technologies.

It is worth mentioning that in this study, a best practice is one that "is connected to educational experiences and teaching practices that integrate free software digital resources and communication networks to create new content and school organizational models, promoting other types of educational activities and 
fostering collaborative work strategies" (De Pablos Pons \& Jiménez Cortés, 2007, p. 26).

The investigation was based on two samples with different characteristics. In the first place, quantitative convenience sampling was used (Hernández Sampieri, 2010), which included Mathematics teachers from the 1st Level of Secondary Education selected from the records and database available (ANEP, 2015; ANEP, 2017; CESInspección de Matemática, 2017; INEEd, 2014). To collect the data, an online questionnaire was sent using the LimeSurvey application. It was a self-administrated online survey that allowed for a greater guarantee of anonymity and less acquiescence, and social desirability of the answers.

Regarding the procedure used, 1593 invitations were sent via email between 8/24/2018 and 9/12/2018. Finally, the voluntary sample was integrated by 176 teachers that replied to the invitation. The average age was 42 years old $(<21,>63$ and $\sigma=9.69)$, with an average teaching experience of 14.8 years $(<1$ and $>40$ years and $\sigma=8.48$ ).

After the quantitative data collection phase, in a second stage, a qualitative sample of teachers who answered the online survey and expressed their interest in being interviewed was selected. For this purpose, at the end of the questionnaire, there was a question in which the teacher expressed their willingness to participate in the qualitative stage. The final sample of 15 teachers originated from a universe of 22 teachers who responded positively to our invitation.

The selection of the theoretical and voluntary sample of 15 teachers followed the purposive sampling procedures according to preset categories that aim to enhance the heterogeneity of the participants (Maxwell, 1996). Interviews were conducted to delve into and explore the network of intervening factors that explain, according to the teachers' representations and meanings, the different types of use of the digital platforms and resources. The evidence was collected based on the following criteria that sought to generate rich and deep knowledge at different levels of heterogeneity related to pedagogical training, the subsystem of the public secondary education, the region where they work, professional experience, and academic level.

The interviews allowed us to meet the objectives related to the gathering of evidence about the technological use of Mathematics content developed by the teachers in m-learning environments with the support of devices such as laptops, cell phones, and digital resources. Besides, according to the teachers' interpretative categories, we were able to understand the factors or barriers that may be hindering the effective development of innovation in teaching with digital technology.
Two types of instruments were designed. In the first place, a structured questionnaire with eight sections that gather the same number of dimensions of analysis.

The validation process of the questionnaire involved eight pilot tests to mathematics teachers with a similar profile to the ones participating in the investigation but that were not part of the sample. Through these tests, it was possible to identify how clear the questions were and the level of adequacy concerning the proposed objectives of this study. For the pre-test, the questionnaire was sent using LimeSurvey so its functioning and the conditions of application of the procedures could be tested (Hernández et al., 2010). By applying the Cronbach's alpha, the validity, reliability, and internal consistency of the two analyzed scales of the instrument were estimated, and their results were 0.72 and 0.87 .

The frequency with which teachers use digital devices with their students in the mathematics classroom was analyzed. This procedure was done through a 4 point Likert-type scale (answers categorized in between extremes of $1=$ "Never" and 2= "Every day").

In particular, this article delves into section $\mathrm{H}$ of the questionnaire, referring to the successful experiences in using technology in the mathematics classroom.

The second instrument used was the semi-structured interview. To design the interview guide, the national and international empirical background was taken into account. In particular, the recommendations of the Taylor et al. (2006) model were used to include in the study the pedagogical dimensions of $\mathrm{m}$-Learning related to the semiotic space and technological space. The interview guide was designed based on sections with questions referring to the following dimensions: using technology and digital tools to support the teaching of Mathematics, investigations based on technologies, Plan CEIBAL, the use of the PAM Platform, digital resources and, barriers in the mathematics classroom.

The analysis of the quantitative data was done using the 25th version of the Statistical Package for the Social Sciences (SPSS) software. Univariate and bivariate descriptive analyses were done: relative and absolute frequency distribution, average, and standard deviation. The qualitative analysis strategy was based on two different sources: the answers from the open question in the survey and the 15 interviews done to the teachers. For the analysis, multiple strategies were used: thematic analysis and recording of frequencies to identify recurrent response patterns, elaboration of categories of use, and construction of an interpretative matrix of the participants' narrative. Preset and emergent interpretative categories were built in keeping with the recommendations of the constant comparative method (Glaser \& Strauss, 1967). In order to visualize the analysis and the reported meanings, evidence was grouped into figures and tables that classify and code the emergent 
Table 1. Characteristics of the categories of use

\begin{tabular}{ll}
\hline Categories & Characteristics \\
\hline $\begin{array}{l}\text { Use of free software with } \\
\text { innovation }\end{array}$ & $\begin{array}{l}\text { The teacher integrates digital resources using free software and participates in } \\
\text { communication networks to create new content and other types of collaborative } \\
\text { digital educational activities. }\end{array}$ \\
$\begin{array}{l}\text { Use of proprietary software } \\
\text { (PAM platform) }\end{array}$ & $\begin{array}{l}\text { The teacher integrates digital resources provided by Plan CEIBAL in the form of } \\
\text { Educational Platforms. Those relevant for this study are PAM and CREA. }\end{array}$ \\
$\begin{array}{l}\text { Use of free software without } \\
\text { innovation }\end{array}$ & $\begin{array}{l}\text { The teacher integrates digital resources using free software, but these have already } \\
\text { been created by others, and the teacher uses them for mathematical exercises. }\end{array}$ \\
\hline
\end{tabular}

data (Miles \& Huberman, 1984). The deductive and emergent categories were processed in a hermeneutical matrix and subsequently triangulated with the qualitative data to add validity and consistency to the analysis (Arias, 2000).

\section{RESULTS}

\section{What are the Teachers' Perceptions of the Use of Digital Platforms, Tools, and Applications in the Mathematics Classroom?}

Among the study's main results, it stands out the high level of the teachers' expectations regarding how the use of digital technology affects teaching processes. Almost all teachers agree that the use of digital tools facilitates the learning of Mathematics (97\%), the vast majority agrees with the statement that the use of digital tools contributes to improving the teaching of Mathematics (95.6\%), that the use of digital tools must be included in the subject syllabus $(87.4 \%)$ and, that in the future it will be necessary to organize virtual exams through the use of platforms (64.4\%).

Nevertheless, despite these high expectations regarding technologies in teaching, the teachers' statements concerning how they are used in real contexts indicate a low predisposition to ICT use in primary and secondary education. It was confirmed that there is little preference for promoting pedagogical work in the classroom supported by technology. Seventy-one percent of the surveyed teachers expressed a low predisposition to the use of digital technologies with their students. Likewise, the surveyed data reported that Mathematics teachers use digital devices with different intensity as instruments to support their teaching. The smartphone was the preferred device by the teachers $(32.2 \%)$ in comparison to the laptops provided by Plan CEIBAL (26.1\%), to the tablets $(22.8 \%)$, and to working with the students in the Computer Lab (21\%).

Last, the quantitative analysis confirmed that GeoGebra is preferred by $55.7 \%$ of the teachers $(\bar{x}=$ 3.56 and $\sigma=0.86)$ and PAM by $49 \%$ of the surveyed teachers $(\bar{x}=3.29$ y $\sigma=1.18)$.

These specific Mathematics applications were the ones that report the highest levels of use, according to the self-perception expressed by the teachers consulted. In the statistical analysis performed, it was found that there was a correlation between the use of PAM and the predisposition to use GeoGebra $(\mathrm{N}=176, \mathrm{r}=0.43)$. At the other end, some applications with a minimum level of use were found, such as Mathgraph (8.6\%), Dr. Geo $(4.1 \%)$. These interactive programs for teaching geometry appear to be relegated, possibly due to the institutionalized use that GeoGebra has in Uruguay (Vaillant et al., 2020).

Of the total number of teachers who voluntarily answered the questionnaire, $47 \%$ consider that they implement best practices mediated by technology.

\section{What is the Teachers' Interpretation Regarding the Implementation of a Best Practice in the Use of Digital Resources in the Teaching of Mathematics?}

To identify best practices based on the use of digital tools, an analysis of the pieces of information containing the teachers' answers in one of the sections of the questionnaire was done. After a process of review and recurrent analysis of meanings, these answers were grouped into three categories of use to be examined and compared. The obtained information was coded and hierarchized, which enabled the determination of three semantic fields that constituted the theoretical categories used for the analysis. These categories are the following: "Use of free software with innovation", "Use of the PAM platform (proprietary software)", and "Use of free software without innovation". Table 1 shows the characteristics of each software.

Next, Table 2 presents a hermeneutical matrix containing the semantic fields and the most recurrent types of narratives associated with each field, which derive from the coding of the open-ended questions.

It was confirmed that $69.9 \%$ of the teachers who answered the open-ended question describe a practice that involves using free software with innovation (GeoGebra, Cabri, Scratch, MathGraph32, Kahoot) that, at the same time, fosters collaborative work strategies and uses communication networks to create new content. Twenty-five percent of the teachers describe a practice that uses the mathematics platform PAM and, $7.2 \%$ implements a practice that, even though it involves the use of free software, it does not report any innovative activities.

On the other hand, the teachers' perception regarding best practices mediated by technology was surveyed through a dichotomous question (Yes/No), and it 
Table 2. Hermeneutical matrix of the teachers' narratives regarding a best teaching practice mediated by digital tools and platforms

Semantic fields Associated testimonies in order of frequency

Use of free Use of GG to work on notable points and lines of a triangle and the Euler line / Use of GG to observe software with the relationship existing between the measure of the sides of a right triangle/ Use of GG to address innovation isometries and their properties/ Use of GG to graph quadratic functions and investigate properties/ The activities designed in GG are uploaded to the web and shared with other groups/ Use of Cabri for the study of different thematic units of Geometry/ Use of programming with Scratch in Geometrical applications/ Use of GG to work with sliders, the gradient of a line/ GG for graphing of 2x2 systems/ Use of Mathgraph to make geometric constructions/ Use of Kahoot as an assessment tool in class, the kids are highly motivated.

Use of the PAM Series of exercises that I create in the PAM/ I use the PAM platform for the EPI (Inclusive

Platform (proprietary software) Pedagogical Space) / I work with crea 2 as a way to keep in touch with the students beyond class time/ The use of PAM for students with curricular adaptation/ Using the PAM platform, I select exercises to introduce a topic/ Use of PAM to consolidate topics seen in class/ Videos in the Crea2 platform.

Use of free Excel to tabulate and graph/ Exercising divisibility concepts (lcm, GCF, criteria) through the software without OnlineMSchool Platform/ Searching books in the CEIBAL digital library/ Questionnaires in innovation Thatquiz

revealed that $47 \%$ of the teachers are in favor of these. These findings allow us to conclude that 1 out of 3 teachers participating in the study promote best practices mediated by technology.

Several of the collected testimonies agree in highlighting that incorporating digital tools in the teaching practices carried out by the teachers generates activities that favorably affect the improvement of the teaching of Mathematics with technology. As it was expressed by the interviewees when justifying the reasons for incorporating them:

\footnotetext{
"It was mainly to work in pairs with the Computer Science Teacher; we tried to use the platform in that coordinated time when we worked together" E7

"the need to update myself and grow as a professional, that despite having large experience in the system I still want to get better"

"from the moment they are proposed to work with the computer, the cell phone or any other digital tool, their motivation is different, and that predisposes them to learn in a different way" E10

"its use must be planned, so that the student can learn more, can know more about Mathematics, study more, understand the processes, reason better, discover, speculate" E8 "because it seemed to me that the kids got more
hooked" E9

"it allows catering to the different learning levels one has in the classroom because students are increasingly more heterogeneous in terms of learning styles" E8
}

Working in pairs collaboratively, the teaching update, the students' motivation, attending the different learning styles; are all substantive aspects that account for favorable scenarios in the improvement of the teaching of Mathematics when technology is incorporated.

Several interviewees' testimonies confirm that the use of digital platforms and tools to learn mathematics is a process of incorporation that is moving from the paradigm of substitution towards the paradigm of pedagogical transformation (Puentedura, 2006).

\footnotetext{
"the possibility of analyzing and observing regularities from the dynamic state of the constructions, that allows you to, in a short time, discuss a wider range of situations than what was traditionally done in the blackboard" E8

"because it allows the student to be the protagonist in their educational process" E10

"they can carry out activities autonomously, without the presence of the teacher, at their homes, at recess, in their free time, and they can make progress in acquiring the content and procedures that they are expected to throughout the year" E10
}

A complementary analysis of the collected pieces of evidence was done, considering as categories of analysis the 4 levels proposed by Puentedura (2006). The systemization of the findings from this new perspective is presented in Table 3.

\section{What Limitations and Obstacles Do Teachers Point out in the Use of Digital Platforms?}

Lastly, a new aspect analyzed was the one referring to the limitations, barriers, or obstacles that, according to 
Table 3. Evidence selected according to categories and subcategories of analysis

\begin{tabular}{|c|c|}
\hline Improvement & \\
\hline Substitution & Augmentation \\
\hline $\begin{array}{l}\text { "Cell phones are also used to } \\
\text { access scientific calculators". }\end{array}$ & $\begin{array}{l}\text { "In fact, I use many } \\
\text { [digital resources], }\end{array}$ \\
\hline E4 & $\begin{array}{l}\text { But... each is used at a } \\
\text { given time, with some } \\
\text { objective". "Videos, for } \\
\text { instance, I usually use } \\
\text { them in Mathematics to } \\
\text { introduce new topics } \\
\text { or to explain something } \\
\text { that remained unclear, } \\
\text { or they are uploaded in } \\
\text { the platform so that the } \\
\text { kids can watch them". } \\
\text { E1 }\end{array}$ \\
\hline
\end{tabular}

"The calculator, always, and then the platform CREA, for instance, where I send them practical activities, activities that do not require printing". E6

"Cell phones, before I was a bit reluctant to using them since you seem to never know what the students are up to, you have to control a

Transformation

\begin{tabular}{|c|c|}
\hline Modification & Redefinition \\
\hline "Platforms, for example, the & "They can also use the \\
\hline PAM. It is one that is often & platform autonomously. In this \\
\hline used and I personally like to & sense, that seems to me one \\
\hline use it in class. Also, it varies & strength the platform has, the \\
\hline depending on the topic I am & fact that the kids on their own \\
\hline teaching, or the group level I & may also select activities and \\
\hline am working with". E1 & receive instant feedback. Also, \\
\hline & $\begin{array}{l}\text { having access to the material } \\
\text { available in the platform". E1 }\end{array}$ \\
\hline
\end{tabular}
lot more because it is a small device, but this year I started using it and I had good experiences". E1

"Since all first-year
students have the tablet
provided by Plan
CEIBAL, they can all
have access to the
resource, one can send
tasks and they can do
them at home". E3

"Since all first-year "[PAM use] The fact that one can work with the different levels, the different abilities, the now the series has a number, different types of students that therefore, I put together a one has within the class". "The series, I share that number parent that gets involved and works with the kid at home comes happy". E2
"The reasons [for using PAM] were many. One of them was that same leveling of the students that you have at different levels, where I can assign series, at different levels student has their own exercises". E2
"The applications, I use them, it terms of GeoGebra, mostly when I work with functions. And it did a great job when I worked with three-by-three systems of equations in fourth grade. In third grade, to work with two-by-two systems, to see the lines, since it has a 3D view they can visualize the positions easily. I have used that one, but... I stay with PAM". E2

"Another thing that was added [to PAM] over the years is that with you and you can have the same series in your platform". E5 the participating teachers' experiences and perceptions, affect the success possibilities of innovations based on technologies. These factors are relevant since they constitute the support through which the conditions for developing educational innovations are produced with the support of digital tools and internet access. The study confirmed a set of objective limitations that hinder the teachers' possibilities to develop superior levels of pedagogical transformation (like the stages or phases of modification and redefinition of educational practices with ICT). These limitations refer to connectivity problems, infrastructure, and software or device limitations. Table 4 shows the main difficulties highlighted by the teachers in the use of digital technology.

Among the reported limitations, a group of teachers identified the malfunctioning of the Wi-Fi networks of the educational centers as a determining factor. This situation is caused by the saturation generated by high user demand at the same time and in the same physical place, findings that coincide with previous studies (Rodríguez Zidán \& Grilli, 2019). It would seem that the ICT policies in Uruguay are victims of their own success; on the one hand, there is increasingly universal access to the internet, but on the other hand, the massive use of resources causes new problems that need to be solved.

From the narrative of the teachers participating in the sample, another type of limitation was confirmed related to the impediment to use digital tools caused by limited and inadequate infrastructure. Likewise, another finding emerging from this investigation, as well as from similar studies (Eudave \& Carbajal, 2011), is the lack of quick technical support in the face of user demands, both for the maintenance of the computers and the renovation of damaged equipment. Teachers point out that although, in theory, the possibility of updating the equipment exists either because it becomes obsolete over time due to the requirements of the new software or due to 
Table 4. Main difficulties pointed out by the teachers that represent barriers to promote changes in the teaching of Mathematics based on digital technologies

\section{Categories Evidence}

Connectivity "they feel demotivated because at the same time, they are very anxious and the computers and the connection is slow, which makes them spend at least 10 to 20 minutes trying to log into the platform". E10

"I like everything, and it is very applicable, but to be honest, it requires planning time, and in practice, I cannot implement it due to the little/poor connectivity in the high school".

"I have not used them this year, but last year, working with Edmodo helped me to assess students in a different way and show them some audiovisual material that due to poor connectivity, we were not able to work with in class. In addition, I find GeoGebra quite useful when working with quadratic functions in order to analyze their characteristics".

"last year and this one, there is more reticence on the part of the students to do homework using PAM because it cannot be installed in the cell phone and students do not use the PC much, and the one from Plan CEIBAL is usually broken down. From the classroom at the high school, it is impossible to use the PAM due to connectivity reasons". E8

Infrastructure "A best practice would be to have available technological tools to implement them. There is no computer lab. The computers provided by ceibal do not have the necessary backup, and the connectivity is insufficient". E9

"I used to work with Scratch to facilitate the introduction to the design of algorithms and encourage different mathematical content based on games, but year after year it has become more difficult and especially this year impossible because the high school classrooms are absolutely outdated" "as well as the tablets that were delivered to $1^{\circ}$ year of Lower Secondary by Plan CEIBAL, which do not support working with that program"

Software limitations "In my second and third-year courses, I use the PAM platform for EPI. This activity is affected by Digital Resources two situations: the first one, the students' computers delivered by Plan Ceibal are in poor conditions and the computer lab is usually busy with another subject. Despite this, students use their phones to fulfill the series that I assign in PAM". E6

constant -and sometimes careless- use, in practice, this does not occur.

\section{DISCUSSION}

The Uruguayan teachers' predisposition to use GeoGebra, in comparison to other dynamic software, coincides with the findings of national (CEIBAL- MAT, 2012; Téliz, 2014) and international (Bulut \& Bulut, 2011; Reisa, 2010; Summak et al., 2010) studies, in which the strengths are recognized for the teaching of geometry over other programs of the same field. It is also emphasized the high level of preference for the PAM Platform implemented by Plan CEIBAL for the teaching of mathematics.

Although approximately half of the participating teachers reported implementing best practices with digital tools in the teaching of mathematics, this relationship drops to a third when the practices described by the teachers in the open-ended question are analyzed, either because they do not use free software that promotes innovative activities, they do not use communication networks to create new content, or they do not encourage collaborative work (De Pablos Pons \& Jiménez Cortés, 2007). The teachers' testimonies demonstrate a favorable perception of incorporating digital tools in their practices since these contribute towards improving the learning of Mathematics. Although, in their narrative, a process of gradual incorporation from a mere substitution of one tool for another to the pedagogical transformation of learning environments with the use of digital technology can also be seen (Puentedura, 2006).

Likewise, it was found that diverse factors limit the impact of using technology in secondary education, such as technological infrastructure, access and Wi-Fi speed in educational institutions, and the availability of mobile devices. The access conditions to technological infrastructure, Wi-Fi networks, and technological equipment is a result that is confirmed by other national studies (Plan CEIBAL, 2015; Vaillant \& Bernasconi, 2012). To overcome this barrier, it is necessary to reinforce policies on equipment repair and the backup programs that support and respond to the technological demands in the educational centers, in the short and medium-term.

A second recommendation based on the findings refers to the need to articulate educational policies at the macro level with the specific context where programs are applied. In this sense, in order to enhance efficiency in the investment of state resources in ICT policies, it is essential to associate the global policy (Plan CEIBAL) with the specific programs (PAM Platform) articulately and coherently. Likewise, it is pressing to support and foster the development of best practices in the use of digital technologies in the context of specific programs to train teachers through more prescriptive proposals 
that frame and give meaning to innovation. In this new scenario, the collected data suggest that both curricular management of the discipline (in charge of the mathematics area inspectors) and the administration of education (principals and supervisors) are called to fulfill a fundamental role of leadership, support, and dissemination of best practices in the use of digital tools.

Author contributions: All authors have sufficiently contributed to the study, and agreed with the results and conclusions.

Funding: No funding source is reported for this study.

Declaration of interest: No conflict of interest is declared by authors.

\section{REFERENCES}

Aboal, D., Bauzán, A., Gómez, M., Méndez, I., Perera, M., \& Pérez, Y. (2018). Factores asociados al uso de la PAM en primaria: el rol de los docentes y las intervenciones de politica [Factors associated with the use of PAM in primary school: the role of teachers and policy interventions]. Centro de Estudios Ceibal. https://digital.fundacionceibal.edu.uy/ jspui/handle/123456789/237

ANEP. (2015). Proyecto de presupuesto período 2015-2019 [Budget project for the 2015-2019 period]. Montevideo (Volume I: Statement of reasons).

ANEP. (2017). Monitor educativo Liceal del Consejo de Educación Secundaria [Liceal educational monitor of the Council of Secondary Education]. Montevideo.

Arias, E., \& Cristia, J. (2014). El BID y la tecnología para mejorar el aprendizaje: ¿Cómo promover programas efectivos? [The IDB and technology to enhance learning: How to promote effective programs?] Banco Interamericano de Desarrollo, BID, Washington, D.C. 20577, USA. Technical Note No. IDB-TN-670. 72 p. https://publications.iadb.org/ publications / spanish/document/El-BID-y-latecnolog\% C3\% ADa-para-mejorar-el-aprendizaje$\% \mathrm{C} 2 \% \mathrm{BFC} \% \mathrm{C} 3 \% \mathrm{~B} 3 \mathrm{mo}$-promover-programasefectivos.pdf

Arias, M. (2000). La triangulación metodológica: sus principios, alcances y limitaciones [Methodological triangulation: its principles, scope and limitations]. Investigación y Educación en Enfermería, 18(1), 13-26.

Attad, C. (2015). Introducing iPads into primary mathematics classrooms: teachers' experiences and pedagogies. In M. Meletiou Mavrotheris, K. Mavrou, \& E. Paparistodemou (Eds.), Integrating touch enabled and mobile devices into contemporary mathematics education (p. 197-217). IGI Global. https: / / doi.org/10.4018/978-1-4666-8714-1.ch009

Bansilal, S. (2015). Exploring student teachers' perceptions of the influence of technology in learning and teaching mathematics. South African Journal of Education, 35(4), 1-8. https:/ / doi.org/10.15700/saje.v35n4a1217
Bentancor Biagas, G. (2017). La matematización: una mirada a las prácticas de enseñanza y evaluación de los docentes del Ciclo Básico de una zona Metropolitana de Montevideo [Mathematization: a look at the teaching and evaluation practices of Basic Cycle teachers in a Metropolitan area of Montevideo] (Master's degree in education thesis). Universidad ORT Uruguay, Montevideo. http://hdl.handle.net/ 20.500.11968/3557

Cabezas González, M., Casillas Martín, S. (2019). Las educadoras y educadores sociales ante la sociedad red [Educators and social educators before the network society]. Ensaio: Avaliação e Politicas Públicas em Educação, 27(104), 521-542. https:/ / doi. org/10.1590/s0104-40362019002701360

Cabrera Borges, C., Cabrera Borges, A., Carámbula, S., Pérez, A., \& Pérez, M. (2018). Tecnologías digitales: análisis de planes de profesorado de Uruguay [Digital technologies: analysis of teaching plans in Uruguay]. Cuadernos de Investigación Educativa, 9(2), 13-32. https:/ / doi.org/10.18861/cied.2018.9.2.2858

Cabrol M., \& Székely, M. (2012) Educación para la transformación [Education for transformation]. BID. https://publications.iadb.org/publications/spani sh/document/Educaci\%C3\%B3n-para-latransformaci \% C3\%B3n.pdf

Chaia, A., Child, F., Dorn, E., Frank, M., Krawitz, M., \& Mourshed, M. (2017). Factores que inciden en el desempeño de los estudiantes: perspectivas de América Latina [Factors influencing student performance: perspectives from Latin America]. McKinsey \& Company.

Chauhan, S. (2017). A meta-analysis of the impact of technology on learning effectiveness of elementary students. Computers $\mathcal{E}$ Education, 105, 14-30. https://doi.org/10.1016/j.compedu.2016.11.005

Creswell, J., \& Plano Clark, V. (2007). Designing and conducting mixed methods research. Sage.

Dussel, I. (Coord). (2014). Incorporación con sentido pedagógico de TIC en la formación docente en los países del Mercosur [Incorporation with a pedagogical sense of ICT in teacher training in the Mercosur countries]. Teseo. http://www.pasem.org/IMG/ pdf/-14.pdf

Eudave Muñoz, D., \& Carvajal Ciprés, M. (2011). Posibilidades y usos de las TIC en educación básica [Possibilities and uses of ICT in basic education] [Paper presentation]. XI National Congress of Educational Research, Mexico City, Mexico. http:/ / www.comie.org.mx/congreso/memoriaele ctronica/v11/docs/area_07/2443.pdf

Furió, D., Juan, M. C., Seguí, I., \& Vivó, R. (2015). Mobile learning vs. traditional classroom lessons: a comparative study. Journal of Computer Assisted 
Learning, 31(3), 189-201. https://doi.org/10.1111/ jcal.12071

Galpering, H. (2013) Los precios de la conectividad en América Latina y el Caribe [The prices of connectivity in Latin America and the Caribbean]. http://live.v1.udesa.edu.ar/files/AdmTecySocied ad/15\%20Galperin.pdf

García Acosta, G. (2002). Uso y disponibilidad de la tecnología educativa en escuelas de educación básica [Use and availability of educational technology in basic education schools]. http://bibliotecadigital. conevyt.org. $\mathrm{mx} /$ colecciones/documentos/somece 2002/Grupo1/garcia.pdf

García Perales, R. (2018). Diseño y construcción de un instrumento de evaluación de la competencia matemática: aplicabilidad práctica de un juicio de expertos [Design and construction of a mathematical competence assessment instrument: practical applicability of an expert judgment]. Ensaio: Avaliação e Políticas Públicas em Educação, 26(99), 347-372. https://doi.org/10.1590/s010440362018002601263

Glaser, B. \& Strauss, A. (1967). The discovery of grounded theory. Aldine Press.

Goehle, G., \& Wagaman, J. (2016). The impact of gamification in web based homework. PRIMUS, 26(6), 557-569. https://doi.org/10.1080/10511970. 2015.1122690

Heerwegh, D., \& Loosveldt, G. (2008). Face-to-face versus web surveying in a high-internet-coverage population: Differences in response quality. Public Opinion Quarterly, 72(5), 836-846. https://doi.org/10.1093/poq/nfn045

Hernández Sampieri, R., Fernández Collado, C., \& Baptista Lucio, P. (2010) Metodología de la investigación [Investigation methodology]. McGraw-Hill.

INEEd (2014) Informe sobre el estado de la educación en Uruguay 2014 [Report on the state of education in Uruguay 2014]. Montevideo. https://www.ineed. edu.uy/images/pdf/informe-educacion-2014.pdf

INEEd, Alonso, C., Bentancor, G., Borba, E., Cuevasanta, D., De Armas, A., Emery, C., González, M., López, R., Lucián, E., Méndez, I., Moreno, L., Núñez, M., Padula, D., Eugenia, M., Panizza, Rajchman, A., \& Reigosa, V. (2020). Aristas 2020. Informe de resultados de tercero de Educación Media [Aristas 2020. Thirdparty results report for Secondary Education]. Montevideo. https://www.ineed.edu.uy/images/ Aristas/Publicaciones/ Aristas2018/ Aristas-2018Informe-de-resultados.pdf

Jara, I. (2015). Revisión comparativa de iniciativas nacionales de aprendizaje móvil en América Latina. El caso del Plan Ceibal de Uruguay [Comparative review of national mobile learning initiatives in Latin America. The case of Uruguay's Plan Ceibal]. UNESCO. http:// cdi.mecon.gov.ar/bases/docelec/az3186.pdf

Lugo, M. \& Delgado, L. (2020). Hacia una nueva agenda digital educativa en América Latina [Towards a new educational digital agenda in Latin America]. CIPPEC (Centro de Implementación de Políticas Públicas para la Equidad y el Crecimiento). Work Document $\mathrm{N}^{\circ} 187$. Buenos Aires. https://www. cippec.org/wp-content/uploads/2020/03/187-

DT-EDU-Hacia-una-nueva-agenda-digitaleducativa-en-Am\%C3\% A9rica-Latina-Lugo-yDelgado-noviembre-de-2019.pdf

Maxwell, J. (1996) Qualitative research design. An interactive approach. Sage Publications.

Mazzotti, W. (2016) Los iTICnerarios docentes: enseñantes recorriendo territorios tecnológicos [The teaching iTICneraries: teachers traveling through technological territories] (Doctoral dissertation). Universidad ORT Uruguay, Montevideo. https:// bibliotecas.ort.edu.uy/bibid/84926/ file/3437

Miles, M., \& Huberman A. (1984). Qualitative data analysis. A source book of new methods. Sage.

Moreira, M. A., Santos, M. B. S. N., \& Mesa, A. L. S. (2018). Las aulas virtuales en la docencia de una universidad presencial: la visión del alumnado [Virtual classrooms in the teaching of a face-to-face university: the vision of the students]. Revista Iberoamericana de Educación a Distancia, 21(2), 179198. https:/ / doi.org/10.5944/ried.21.2.20666

OCDE (2013) Pisa 2012 Assessment and analytical framework: mathematics, reading, science, problem solving and financial literacy. Paris.

OCDE (2015) Talis: teaching in focus: enseñar con tecnologías [Talis: teaching in focus: teaching with technologies]. Paris.

OCDE (2019). Talis 2018 Docentes y directores de centros educativos como estudiantes de por vida [Teachers and directors of educational centers as lifelong students]. International Study on Teaching and Learning.

Palomo, R., Ruiz, J., \& Sánchez, J. (2006). Las TIC como agentes de innovación educativa [ICT as agents of educational innovation]. Junta de Andalucía, Consejería de Educación, Dirección General de Innovación Educativa y Formación del Profesorado.

Plan CEIBAL (2015). Evolución de la brecha de acceso a TIC en Uruguay (2007-2014) y la contribución del Plan Ceibal a disminuir dicha brecha [Evolution of the ICT access gap in Uruguay (2007-2014) and the contribution of Plan Ceibal to reducing this gap]. Departamento de Monitoreo y Evaluación del Plan Ceibal. http://dspace.mides.gub.uy:8080/xmlui/ handle/123456789/457 
Pons, J., \& Cortés, R. (2007). Buenas prácticas con TIC apoyadas en las Políticas Educativas: claves conceptuales y derivaciones para la formación en competencias [Good practices with ICT supported by Educational Policies: conceptual keys and derivations for skills training]. Revista Latinoamericana de Tecnología Educativa-RELATEC, $6(2), 15-28$.

Puentedura, R. (2006). Transformation, technology, and education. http:/ / hippasus.com/resources/tte/

Rivera-Vargas, P., \& Cobo-Romani, C. (2020). Digital learning: distraction or default for the future. Digital Education Review, (37). https://revistes.ub. edu/index.php/der/article/view/31813

Rodriguez Zidán, E., \& Grilli Silva, J. (2019). El blearning en los cursos semipresenciales y presenciales de la formación inicial de profesores de ciencia en Uruguay [B-learning in the blended and face-to-face courses of the initial training of science teachers in Uruguay]. In Ciencia, Docencia Tecnología. https://doi.org/10.33255/3059/691

Rodríguez Zidán. E., Marcelo, C., Bernasconi, G., Yot, C. \& Téliz, F. (2017). Educadores en la era digital: aprender a enseñar con tecnologías en la formación inicial de profesores de educación media en Uruguay [Educators in the digital age: learning to teach with technologies in the initial training of secondary school teachers in Uruguay]. Instituto de Educación, Universidad ORT Uruguay.

Sunkel, G., Trucco, D. \& Espejo, A. (2014). La integración de las tecnologías digitales en las escuelas de América
Latina y el Caribe Una mirada multidimensional [The integration of digital technologies in schools in Latin America and the Caribbean A multidimensional view]. Comisión Económica para América Latina y el Caribe (CEPAL) Santiago de Chile.

Taylor, J., Sharples, M., O'Malley, C., Vavoula, G., \& Waycott, J. (2006). Towards a task model for mobile learning: A dialectical approach. International Journal of Learning Technology, 2(2-3), 138-158. https:/ / doi.org/10.1504/IJLT.2006.010616

UNESCO. (2016). Revisión comparativa de iniciativas nacionales de aprendizaje móvil en América Latina. El caso del Plan Ceibal de Uruguay [Comparative review of national mobile learning initiatives in Latin America. The case of Uruguay's Plan Ceibal]. Buenos Aires: Unesco.

Vaillant, D., \& Bernasconi, G. (2012). El Plan Ceibal y las prácticas de los docentes de Matemática en primer año de liceo [The Ceibal Plan and the practices of mathematics teachers in the first year of high school]. Instituto de Educación, Universidad ORT Uruguay. https://dspace.ort.edu.uy/handle/20. 500.11968/4179

Vaillant, D., Rodríguez Zidán, E., \& Bentancor Biagas, G. (2020). Uso de plataformas y herramientas digitales para la enseñanza de la Matemática [Use of digital platforms and tools for teaching Mathematics]. Ensaio: Avaliação e Políticas Públicas em Educação, 28(108), 718-740. https://doi.org/10.1590/s010440362020002802241

\section{http://www.ejmste.com}

